\title{
LAMA WAKTU FERMENTASI DAN KONSENTRASI RAGI PADA PEMBUATAN TEPUNG TAPE SINGKONG (Manihot utilissima) MENGANDUNG DEKSTRIN, SERTA APLIKASINYA PADA PEMBUATAN PRODUK PANGAN
}

\author{
Long Time Fermentation and Yeast Concentration on Making Tape Flour Cassava \\ (Manihot utilissima) Contains Dextrin, and its Application on Making Food Products
}

\author{
Anto Susanto ${ }^{1)}$, Erick Radwitya ${ }^{2)}$, Khairul Muttaqin ${ }^{3)}$ \\ ${ }^{1)}$ Program Studi Agroindustri Politeknik Negeri Ketapang \\ 2). Program Studi Teknik Elektro Politeknik Negeri Ketapang \\ ${ }^{3)}$ Program Studi Teknik Pertambangan Politeknik Negeri Ketapang
}

\begin{abstract}
Fresh cassava can not be stored for long, while the shelf life is only between 4-5 days. At the time of harvest, cassava plants are sometimes not able to provide a lot of benefits for farmers, especially farmers in the district of Ketapang because in addition to tubers easily damaged, the selling price is very low. To overcome these problems, it is necessary to process the cassava into a variety of processed products. Processed cassava in addition can extend its shelfability can also provide a large enough profit for farmers. One of them is the manufacture of high cassava tape flour tape made through the process of fermentation. The results of the research on the duration of fermentation and yeast concentration on the manufacture of cassava flour (Manihot utilissima) contain dextrin, as well as its application in the manufacture of food products, showing that: (1). The best fermentation period range in the manufacture of cassava flour tape contains dextrin for 25 hours; (2). The best yeast tape concentration on the manufacture of cassava tape flour contains $2 \%$ dextrin; (3). At $2 \%$ yeast tape concentration with a 25-hour fermentation period resulted in physico-chemical properties of cassava tape flour containing dextrin, such as the value of dextrin content of 9.897\%; Sugar reduction $13.453 \%$; Water content $8.8 \%$; Ash content of 1.6\%; Total acid 1.96\%; PH value 5.2; And yield of 37.3\%; And (4). The favorite level of brownie with the ratio of cassava flour tape containing $100 \%$ dextrin: $0 \%$ wheat flour preferably by panelists with an average value of aroma 7.04, 6.84 texture and 6.96 flavors.
\end{abstract}

Keywords: flour, cassava, dextrin, brownies

\begin{abstract}
ABSTRAK
Singkong segar tidak dapat disimpan lama, adapun masa simpannya hanyalah berkisar antara 4-5 hari. Pada masa panen, tanaman Singkong kadang-kadang tidak mampu memberikan keuntungan yang banyak bagi petani, khususnya petani di wilayah Kabupaten Ketapang karena disamping umbinya mudah rusak, harga jualnyapun sangat rendah. Untuk mengatasi masalah tersebut, sangat diperlukan adanya upaya pengolahan Singkong menjadi berbagai macam produk olahan. Olahan Singkong selain dapat memperpanjang daya simpannya juga dapat memberikan keuntungan yang cukup besar bagi para petani. Salah satunya adalah pembuatan tepung tape Singkong tinggi dekstrin dibuat melalui proses fermentasi. Hasil penelitian pada lama waktu fermentasi dan konsentrasi ragi pada pembuatan tepung tape singkong (Manihot utilissima) mengandung dekstrin, serta aplikasinya pada pembuatan produk pangan, menunjukan bahwa : (1). Kisaran periode fermentasi terbaik pada pembuatan tepung tape singkong mengandung dekstrin selama 25 jam; (2). Konsentrasi ragi tape terbaik pada pembuatan tepung tape singkong mengandung dekstrin 2\%; (3). Pada konsentrasi ragi tape $2 \%$ dengan kisaran periode fermentasi 25 jam menghasilkan sifat fisiko-kimia tepung tape singkong mengandung dekstrin, diantaranya nilai kadar dekstrin 9,897\%; gula reduksi 13,453\%; kadar air $8,8 \%$; kadar abu 1,6\%; total asam 1,96\%; nilai pH 5,2; dan rendemen 37,3\%.; dan (4). Tingkat kesukaan brownies dengan perbandingan tepung tape singkong mengandung dekstrin 100\%:0\%
\end{abstract}


tepung terigu lebih disukai oleh panelis dengan nilai rata-rata aroma 7,04; tekstur 6,84 dan rasa 6,96 .

Kata kunci : tepung, singkong, dekstrin, brownies

\section{PENDAHULUAN}

Potensi ubi kayu di negara Indonesia sangatlah besar baik ditinjau dari sisi sebagai sumber bahan pangan utama, yaitu karbohidrat setelah padi dan jagung, maupun sebagai bahan pakan dan bahan baku industri. Ketela pohon yang lebih sering dikenal dengan sebutan ubi kayu merupakan salah satu produk hasil hortikultura negara Indonesia. Berdasarkan data Badan Pusat Statistik (2011), produktivitas singkong di Indonesia mencapai 24.009.624 ton.

Singkong/ubi kayu di Kabupaten Ketapang sendiri ketersediaannya juga cukup berlimpah, harganya terjangkau oleh masyarakat. Namun, olahan ubi kayu di Kabupaten Ketapang, khususnya daerah penghasil Singkong di Desa Tempurukan Muara Pawan, Ketapang masih konvensional, kurang menarik dan belum diminati oleh konsumen. Produksi komoditas Singkong di Kabupaten Ketapang mengalami peningkatan pada tahun 2012, yaitu sebesar 10.260 Ton, jika dibandingkan pada tahun sebelumnya, yaitu pada tahun 2011 hanya sebesar 8.512 Ton.

Pada masa panen, tanaman ubi kayu kadang-kadang tidak mampu memberikan keuntungan yang banyak bagi petani, karena disamping umbinya mudah rusak, harga jualnyapun sangat rendah. Untuk mengatasi masalah tersebut, sangat diperlukan adanya upaya pengolahan ubi kayu menjadi berbagai macam produk olahan. Olahan ubi kayu selain dapat memperpanjang daya simpannya juga dapat memberikan keuntungan yang cukup besar bagi para petani. Hal ini penting dilakukan mengingat pemanfaatan ubi kayu selama ini hanya diolah menjadi bahan setengah jadi. Salah satu solusi teknologi dengan memanfaatkan bahan dasar ubi kayu menghasilkan berbagai olahan yang menarik, diminati konsumen dan harga tetap terjangkau sekaligus meningkatkan mutu olahan ubi kayu. Diantaranya produk modifikasi olahan ubi kayu melalui fermentasi, untuk menghasilkan tepung tape singkong tinggi dekstrin.

Dekstrin merupakan polisakarida yang dihasilkan dari hasil hidrolisis pati (terutama amilosa) yang memilki struktur linier yang dibentuk oleh unit D-glukosa yang dihubungkan satu sama lain oleh ikatan $\alpha$ 1,4 glikosidik (Kusnandar, 2010). Hidayat (2008), menyebutkan dekstrin adalah karbohidrat yang dibentuk selama hidrolisis pati menjadi gula oleh panas, asam dan atau enzim. Dekstrin dan pati memiliki rumus umum yang sama $-[\mathrm{Cx}(\mathrm{H} 2 \mathrm{O}) \mathrm{y})] \mathrm{n}-(\mathrm{y}=\mathrm{x}$ $-1)$.

Aplikasi pembuatan tepung tape tinggi dekstrin pada penelitian ini akan digunakan untuk produk pangan, diantaranya pembuatan brownies. Selain itu juga, tepung tape tinggi dekstrin merupakan solusi terbaik untuk meningkatkan nilai jual singkong dan mempertahankan daya simpan singkong dalam bentuk tepung yang memiliki kelebihan tersendiri yaitu tinggi dekstrin. Tepung singkong tinggi dekstrin juga merupakan upaya penganekaragaman pangan lokal, yang merupakan komoditas unggul daerah. Dengan adanya tepung tape Singkong tinggi dekstrin tersebut, harapnya dapat mengantikan, atau minimal dapat mengurangi ketergantungan akan tepung gandum yang di eksport dari luar negeri, yang selama ini banyak di konsumsi oleh masyarakat Indonesia. Menurut BPS (2010) dalam Zuhriani (2015), selama ini Indonesia merupakan Negara pengimpor gandum terbesar ke empat di dunia dengan volume impor mencapai 554 ribu ton pada tahun 2008. Jika keadaan ini dibiarkan, ketergantungan pangan dari luar negeri dapat meningkatkan pengeluaran devisa negara. Selain itu, menyebabkan beberapa 
industri makanan berbasis terigu mengalami ketergantungan terhadap tepung terigu. Oleh karena itu perlu adanya upaya untuk mengurangi ketergantungan terhadap penggunaan tepung terigu yaitu dengan mengalihkan penggunaan tepung terigu ke non terigu (Fatkurahman, 2012; Zuhriani, 2015).

Pembuatan brownies berbasis tepung tape Singkong tinggi dekstrin, merupakan salah satu upaya disversifikasi pangan berbasis komoditas lokal daerah, dan hal ini sejalan dengan program pemerintah pusat, maupun pemerintah daerah tentang pemanfaatan dan pengembangan komoditas lokal di daerahnya masing-masing, dalam upaya merealisasikan program ketahanan pangan dan energi terbarukan. Harapannya pemanfaatan dan pengembangan komoditas Singkong tersebut akan meningkatkan diversifikasi produk olahan pangan yang akhirnya berakibat pada naiknya nilai ekonomis Singkong, dan meningkatkan kesejahteraan petani.

Pada penelitian pendahuluan dikaji berapakah kisaran periode fer-mentasi dan konsentrasi ragi terbaik untuk menghasilkan tepung tape Singkong yang mengandung dekstrin tinggi. Penelitian lanjutan dilakukan dalam 2 tahap yaitu pembuatan tepung ubi kayu tinggi dekstrin (tahap 1) dan aplikasi tepung ubi kayu tinggi dekstrin dalam pembuatan produk pangan, yaitu brownies (tahap 2).

\section{METODE PENELITIAN}

\section{Lokasi dan waktu}

Pelaksanaan penelitian dilakukan di Laboratorium Rekayasa Jurusan Teknologi Pertanian Politeknik Negeri Ketapang, untuk uji mutu hasil penelitian dilakukan di Laboratorium Mutu Jurusan Teknologi Pertanian Politeknik Negeri Ketapang. Adapun waktu pelaksanaan penelitian dilakukan selama enam bulan.

\section{Alat dan bahan}

Alat dan bahan yang digunakan dalam pembuatan tepung tape Singkong adalah
Singkong dari Desa Tempurukan Ketapang, ragi tape, alat masak rumah tangga, serbet, timbangan, cabinet dryer, alat penepung, alat mixer, baskom, ember, pengaduk, sendok, oven, blender, ayakan stainless steel 80 mesh, plastik kemas dan sealer. Bahan untuk pembuatan brownies adalah tepung tape Singkong tinggi dekstrin, gula, tepung terigu, mentega, coklat, telur, pengemulsi.

Alat dan bahan untuk pengujian fisikokimia yaitu cawan porselen, oven, timbangan, erlemeyer $600 \mathrm{ml}$, gelas ukur, labu takar, $200 \mathrm{ml}$ larutan $\mathrm{H}_{2} \mathrm{SO}_{4}(1,25 \mathrm{~g}$ $\mathrm{H}_{2} \mathrm{SO}_{4}$ pekat/100 $\left.\mathrm{ml}=0,225 \mathrm{~N} \mathrm{H}_{2} \mathrm{SO}_{4}\right)$, labu Kjedhal, Soxhlet, pendingin balik, tanur, desikator, penetrometer, sentrifuse, tabung reaksi, oven, waterbath, corong, lumpang dan mortal, pipet gondok, kertas saring, $\mathrm{pH}$ meter, $\mathrm{NaOH} 0,1 \mathrm{~N}$, phenolptalien, larutan $\mathrm{I}_{2}, 0,01 \mathrm{~N}$, gelas ukur $50 \mathrm{ml}$, indikator pati dan akuades.

\section{Rancangan penelitian}

Rancangan penelitian Pembuatan tepung ubi kayu tinggi dekstrin yang digunakan pada penelitian ini menggunakan Rancangan Acak Kelompok dengan dua (2) faktor yaitu konsentrasi (R) ragi tape dan periode $(\mathrm{P})$ fermentasi. Konsentrasi $(\mathrm{R})$ ragi terhadap berat ubi kayu kukus terdiri atas $\mathrm{R} 1=1 \%(\mathrm{~b} / \mathrm{b}) ; \mathrm{R} 2=2 \%(\mathrm{~b} / \mathrm{b}) ;$ dan $\mathrm{R} 3=3 \%$ $(\mathrm{b} / \mathrm{b})$. Periode $(\mathrm{P})$ fermentasi yang terdiri $\mathrm{P} 1$ $=20$ jam; $\mathrm{P} 2=25$ jam; dan $\mathrm{P} 3=30$ jam.

\section{Proserdur kerja}

Tahap 1. Pembuatan tape Singkong tinggi dekstrin (Rambing, 2013). Preparasi bahan dalam pembuatan ubi kayu terfermentasi meliputi memilih ubi kayu yang bermutu, pengupasan kulit, penghilangan lendir dan pencucian. Ubi kayu dikukus setengah matang (15 - 20 menit) dan didinginkan. Selanjutnya diinukolasikan dengan ragi tape sesuai perlakuan $1 \%$, $2 \%$ dan 3\% dan ditutup dengan serbet kering. Proses selanjutnya yaitu ubi kayu difermentasi selama 20, 25 dan 30 jam. Pengamatan dilakukan terhadap uji kualitatif 
warna dengan larutan $\mathrm{I}_{2}$. Pada kisaran periode fermentasi tersebut diharapkan diperoleh tepung tinggi dekstrin, dengan parameter hasil pengataman sampel berwarna merah kecoklatan.

Tahap II. Pembuatan tepung Singkong tinggi dekstrin (Rambing, 2013). Pada pembuatan tepung Singkong tinggi dekstrin, Singkong hasil fermentasi dikecilkan ukurannya, dikeringkan dalam cabinet dryier pada suhu $50^{\circ} \mathrm{C}$ selama 24 jam, digiling, diayak dengan ayakan 80 mesh dan dikemas. Tepung selanjutnya dianalisis variabel fisikokimia dan sensorinya. Variabel fisikokimia yang diamati meliputi : Nilai total asam, $\mathrm{pH}$, kadar air, kadar abu, kadar gula menggunakan handrefraktometer, rendemen. Variabel sensori meliputi : warna, flavour, aroma asam, dan aroma etanol.

Tahap III. Aplikasi tepung tape Singkong tinggi dekstrin dalam pembuatan produk pangan (brownies) dengan perbandingan terhadap tepung tapioka

\section{Variabel penelitian}

Adapun variabel dan pengukuran mutu pada penelitian, meliputi : Uji kualitatif warna dengan yodium (Sudarmadji et al., 1997); Nilaikadar dekrosa ekivalen (DE), Nilai kadar gula, Kadar air (Sudarmadji et al., 1997); Kadar abu (Sudarmadji et al.,1997); Kadar total asam (Jacobs, 1962; Rambing, 2013); Nilai pH atau derajat keasaman (Hadioetomo, 1990; Rambing, 2013); Rendeman (Sudarmadji et al., 1997); dan Uji sensori (Soekarto,1985; Rambing, 2013).

\section{HASIL DAN PEMBAHASAN}

\section{Uji kandungan dekstrin tape singkong}

Periode fermentasi dan konsentrasi ragi tape dalam pembuatan tepung tape singkong mengandung dekstrin Uji warna yang dilakukan pada tape singkong dengan menggunakan iodin bertujuan untuk mengetahui kandungan dekstrin yang terdapat pada tape singkong dengan perlakuan waktu fermentasi dan konsentrasi ragi yang berbeda-beda. Pengujian reaksi warna dilakukan dengan cara mengamati perubahan warna yang terbentuk selama 4-5 menit. Terbentuknya dekstrin akan terlihat dari terbentuknya warna merah kecoklatan (Hidayat,2009). Hasil uji warna pada tepung tape singkong dengan menggunakan iodin dapat dilihat pada Tabel 1.

Berdasarkan hasil uji warna, tepung tape singkong yang mengandung dekstrin yaitu pada waktu fermentasi 25 jam dan konsentrasi ragi $2 \%$ dan waktu fermentasi 30 jam dan konsentrasi ragi 3\%. Dari kedua perlakuan tersebut pada waktu fermentasi 25 jam dan konsentrasi ragi $2 \%$ yang digunakan untuk membuat tepung tape singkong mengandung dekstrin, karena dilihat dari segi waktu fermentasi serta penggunaan ragi yang lebih efisien.

Tabel 1. Hasil pengamatan warna dekstrin pada tape singkong

\begin{tabular}{lcccc}
\hline & & \multicolumn{3}{c}{ Konsentrasi ragi (\%) } \\
\cline { 2 - 5 } & & 1 & 2 & 3 \\
\cline { 2 - 5 } $\begin{array}{c}\text { Waktu } \\
\text { (Jam) }\end{array}$ & Coklat & Coklat & Coklat \\
\cline { 2 - 5 } & 25 & Coklat & $\begin{array}{c}\text { Coklat } \\
\text { kemerahan }\end{array}$ & Coklat \\
\cline { 2 - 5 } & 30 & $\begin{array}{c}\text { Merah } \\
\text { muda }\end{array}$ & $\begin{array}{c}\text { Merah } \\
\text { muda }\end{array}$ & $\begin{array}{c}\text { Coklat } \\
\text { kemerahan }\end{array}$ \\
\hline
\end{tabular}

Sumber : Data Primer, 2017

Selain itu, semakin banyak ragi yang ditambahkan dan semakin panjang waktu fermentasi tekstur bahan semakin lembut. Tekstur yang lembut akan mempersulit dalam pengecilan ukuran pada saat proses pembuatan tepung.

\section{Fisiko-kimia tepung tape singkong mengandung dekstrin}

\section{Nilai kadar dekrosa ekivalen (DE)}

Peningkatan kadar dekstrosa ekivalen pada perlakuan konsentrasi $2 \%$ dengan lama fermentasi 25 jam diduga karena adanya aktifitas mikrobia maksimal pada penguraian komponen bahan dalam pemecahan karbohidrat menjadi senyawa gula. Enzim yang semakin banyak akan meningkatkan aktivitas ragi dalam menghidrolisis ubi kayu dan pembentukan 
dekstrin semakin banyak. Penurunan kadar dekstrosa ekivalen pada konsentrasi ragi tape $2 \%$ pada waktu fermentasi 30 jam diduga karena proses hidrolisis terus berjalan sehingga sebagian dekstrin yang terbentuk telah diubah menjadi glukosa lebih lanjut. Hasil analisa kadar dekstrosa ekivalen disajikan pada Gambar 1. kandungan dekstrin tepung tape singkong.

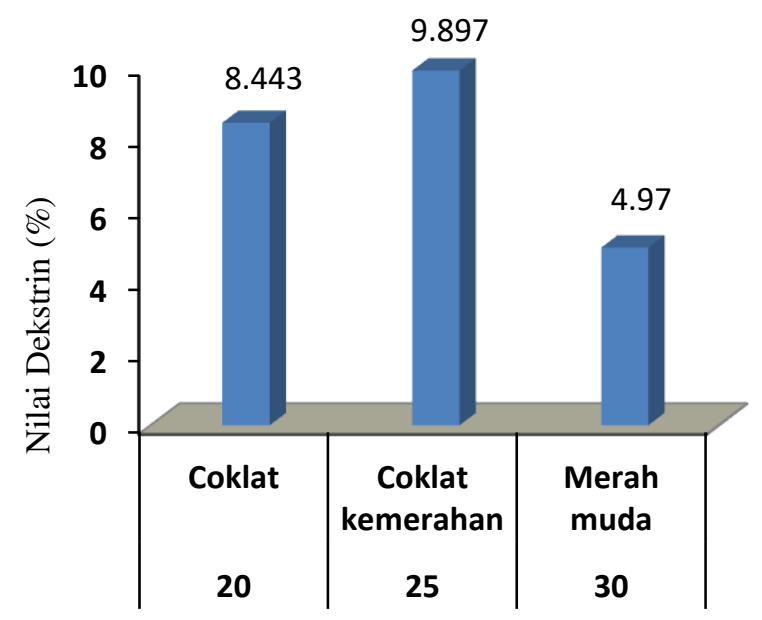

Lama Fermentasi (Jam)

Gambar 1. Kandungan dekstrin tepung tape singkong

Penelitian terdahulu yang dilakukan Zusfahair dan Ningsih (2007), tentang pembuatan dekstrin dari pati ubi kayu menggunakan katalis amilase hasil fraksinasi dari Azospirillum sp. JG3 menghasilkan produk dengan kadar DE 13,3. Maltodekstrin adalah hasil hidrolisis pati dengan kadar DE kurang dari 20 (DeMan, 1997). Sifat fisiko-kimia tepung tape mengandung dekstrin, disajikan pada Gambar 2. fisiko-kimia tepung tape singong mengandung dekstrin.

Kadar gula yang dihasilkan pada tepung tape singkong mengandung dekstrin akibat proses fermentasi yang berlangsung mikroba akan memecah pati menjadi komponen gula-gula sederhana, sehingga kadar pati semakin lama semakin menurun.

Selain itu juga aktivitas enzim amilase yang terkandung dalam ubi kayu akan bekerja secara optimum dalam menghidrolisis pati menjadi komponen yang lebih sederhana.

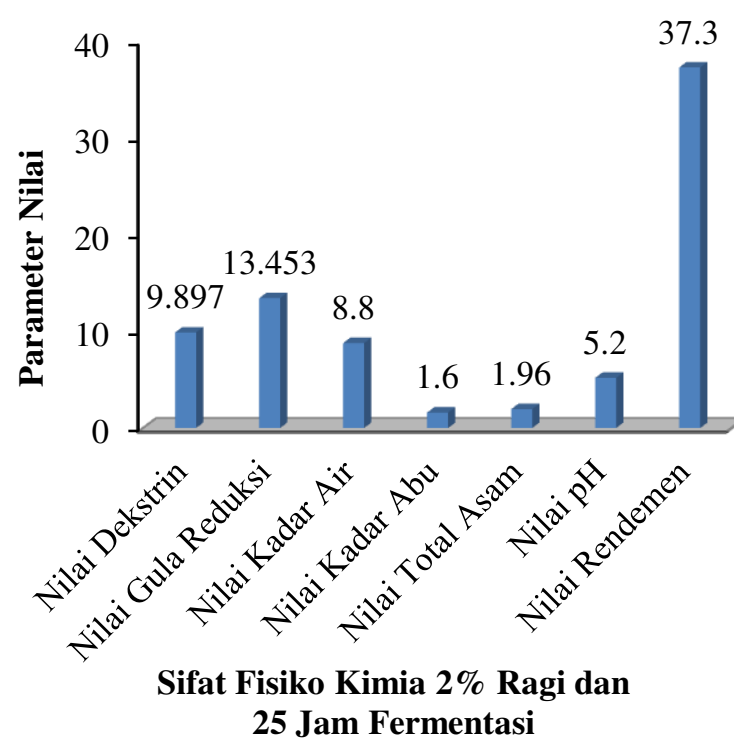

Gambar 2. Sifat fisiko-kimia tepung tape singkong mengandung dekstrin

Menurut Fauzan (2010), penambahan waktu fermentasi akan memberikan kesempatan mikrobia, enzim atau asam bekerja sehingga proses hidrolisis berlangsung terus. Periode fermentasi yang semakin panjang memungkinkan mikrobia terus menghidrolisis pati bahan sehingga gula sederhana yang terbentuk semakin banyak. Berdasarkan data tersebut diketahui bahwa kadar gula reduksi semakin naik dengan meningkatnya konsentrasi ragi yang digunakan. Hal ini diduga karena aktivitas kapang dalam menghidrolisis pati semakin meningkat seiring dengan penambahan konsentrasi ragi. Hal ini menyebabkan pembentukan gula sederhana (glukosa) yang terukur sebagai gula reduksi menjadi lebih banyak. Hidayat et al. (2006) menyatakan bahwa perubahan biokimia yang penting dalam pembuatan tape adalah hidrolisis pati menjadi glukosa dan maltosa yang akan memberikan rasa manis serta perubahan glukosa menjadi alkohol dan asam organik. Kapang Amylomyces roxii dapat menghidrolisis pati menjadi gula (glukosa dan fruktosa). Glukosa dan fruktosa merupakan gula reduksi (Desroiser, 2008).

Kadar air merupakan banyaknya air yang terkandung dalam bahan yang dinyatakan dalam persen. Kadar air dalam 
bahan pangan ikut menentukan kesegaran dan daya awet bahan pangan tersebut (Winarno, 2004). Pengujian kadar air pada tepung tape singkong tinggi dekstrin menggunakan metode pemanasan dengan menggunakan oven. Pada penelitian ini metode yang digunakan adalah metode dengan menggunakan oven.

Pemanasan dilakukan untuk menghilangkan kandungan air yang terdapat pada sampel, hingga berat sampel mencapai berat konstan yaitu 0,0002. Pemanasan yang dilakukan pada penelitian ini yaitu selama 34 kali.

Penurunan kadar air juga dapat disebabkan karena terbentuknya panas akibat proses fermentasi. Pada fermentasi lebih dari 24 jam terjadi senyawa-senyawa organik oleh adanya aktivitas enzim yang menghasilkan senyawa sederhana juga hasil lain dari proses metabolisme yaitu $\mathrm{H}_{2} \mathrm{O}$, energi dalam bentuk panas dan bahan-bahan lainnya. Panas yang terbentuk selama proses fermentasi menyebabkan suhu bahan meningkat dan air yang dihasilkan akan menguap sehingga terjadi penurunan kadar air. Semakin lama periode fermentasi maka panas sebagai hasil metabolisme meningkat dan menyebabkan kadar air semakin menurun (Medikasari et al., 2009; Rambing, 2013).

Abu adalah zat organik sisa hasil pembakaran suatu bahan organik. Kadar abu merupakan campuran dari komponen anorganik atau mineral yang terdapat pada suatu bahan pangan. Kandungan abu dan komposisinya tergantung pada bahan dan cara pengabuannya. Nilai kadar abu pada tepung tape singkong mengandung dekstrin yaitu $1,6 \%$. Hal ini karena tepung tape singkong ini sebagian besar bahannya masih mengandung komponen bahan anorganik yang tinggi. Apabila dibandingkan dengan komposisi kimia mocaf, nilai kadar abu tepung ini cukup tinggi. Berdasarkan komposisi kimianya, kadar abu mocaf maksimal 0,2 \%. Kadar abu dari suatu bahan menunjukkan total mineral yang terkandung dalam bahan tersebut (Aprilianto, 1988).
Kadar total asam adalah nilai yang menunjukkan total asam yang terkandung dalam suatu bahan. Berdasarkan Gambar 2 . sifat fisiko-kimia tepung tape singkong mengandung dekstrin, kadar total asam yang dihasilkan pada tepung tape singkong mengandung dekstrin dapat dipengaruhi oleh konsentrasi ragi yang digunakan untuk fermentasi. Pati di dalam ubi kayu dirombak menjadi senyawa yang lebih sederhana (glukosa) oleh mikroba dan akan dimanfaatkan sebagai nutrisi untuk pertumbuhan, hal inilah yang akan menyebabkan terbentuknya total asam pada ubi kayu. Semakin banyak mikroba yang tumbuh di dalam ubi kayu, maka hasil metabolisme yang berupa asam ini juga akan meningkat. Asam yang dihasilkan oleh mikroba akan tereksresikan keluar sel dan akan terakumulasi dalam media fermentasi sehingga meningkatkan keasaman (Wijayanti, 2006).

$\mathrm{pH}$ adalah ukuran konsentrasi ion hidrogen dari larutan. Pengukuran $\mathrm{pH}$ (potensial hidrogen) akan mengukur jika larutan bersifat asam atau basa. Jika larutan tersebut memiliki jumlah molekul asam dan basa yang sama, $\mathrm{pH}$ dianggap netral. Berdasarkan pengukuran pHdengan menggunakan $\mathrm{pH}$ meter, menunjukkan $\mathrm{pH}$ tepung tape singkong tinggi dekstrin yaitu 5,2. Kisaran $\mathrm{pH}$ tersebut merupakan $\mathrm{pH}$ asam, karena semakin rendah nilai $\mathrm{pH}$ menunjukkan tingginya keasaman dari suatu produk. Nilai $\mathrm{pH}$ semakin turun dengan meningkatnya periode fermentasi. Hal ini diduga karena terbentuknya asam akibat pemecahan pati yang berlangsung terus dengan panjangnya periode fermentasi. Semakin lama waktu fermentasi, pati yang tersedia terhidolisis dan menghasilkan asam (Rambing, 2013).

Rendemen merupakan presentase dari jumlah produk yang dihasilkan dengan jumlah bahan dasar yang digunakan. Rendemen didapatkan dari menbandingkan berat awal bahan dengan berat akhirnya. Sehingga dapat di ketahui kehilangan beratnya proses pengolahan. Singkong yang digunakan untuk membuat tepung tape 
singkong tinggi dekstrin yaitu $15 \mathrm{~kg}$, dengan berat akhir (berat tepung yang dihasilkan) $5,6 \mathrm{~kg}$. Sehingga hasil rendemen dari pembuatan tepung tape singkong tinggi dekstrin yaitu 37,3\%. Hal ini disebabkan karena bahan baku awal yaitu ubi kayu terfermentasi memang masih banyak mengandung air sehingga setelah pengeringan akan mempengaruhi rendemennya.

\section{Uji sensori produk brownies berbasis tepung tape singkong mengandung dekstrin}

Uji organoleptik merupakan suatu pengukuran ilmiah dalam mengukur dan menganalisa karakteristik suatu bahan pangan yang diterima oleh indera penglihatan, pencicipan, penciuman, perabaan, dan menginterpretasikan reaksi dari akibat proses penginderaan yang dilakukan oleh manusia, juga bisa disebut panelis sebagai alat ukur.

Tingkat kesukaan konsumen dapat diukur menggunakan uji organoleptik melalui alat indra. Kegunaan uji ini diantaranya untuk pengembangan produk baru (Soekarto, 1985). Uji kesukaan pada dasarnya merupakan pengujian yang panelisnya mengemukakan responnya yang berupa senang tidaknya terhadap sifat bahan yang diuji. Pengujian ini umumnya digunakan untuk mengkaji reaksi konsumen terhadap suatu bahan.

Metode pengujian mutu organoleptik bahan pangan digunakan untuk membedakan kualitas bahan pangan pada aroma, rasa dan tekstur secara langsung. Mutu organoleptik dari suatu bahan pangan akan mempengaruhi diterima atau ditolak bahan pangan tersebut oleh konsumen sebelum menilai kandungan gizi dari bahan pangan.

\section{Aroma}

Aroma adalah reaksi dari makanan yang akan mempengaruhi konsumen sebelum konsumen menikmati makanan, konsumen dapat mencium makanan tersebut. Aroma memiliki peranan penting untuk produk makanan karena pengujian terhadap bau atau aroma dapat memberikan hasil penilaian terhadap produk tentang diterima atau tidaknya produk tersebut. Produk tersebut akan diterima oleh masyarakat apabila aroma dari produk tersebut tidak menyengat atau hambar (Kartika, 1988; Zuhriani, 2015). Hasil nilai rata-rata uji organoleptik aroma pada brownies disajikan pada Gambar 3. Perbandingan tepung tape singkong mengandung dekstrin dengan tepung terigu pada pembuatan produk brownies. Hasil uji organoleptik terhadap aroma bertujuan untuk mengetahui tingkat respon panelis mengenai kesukaannya terhadap brownies panggang pada masing-masing perlakuan.

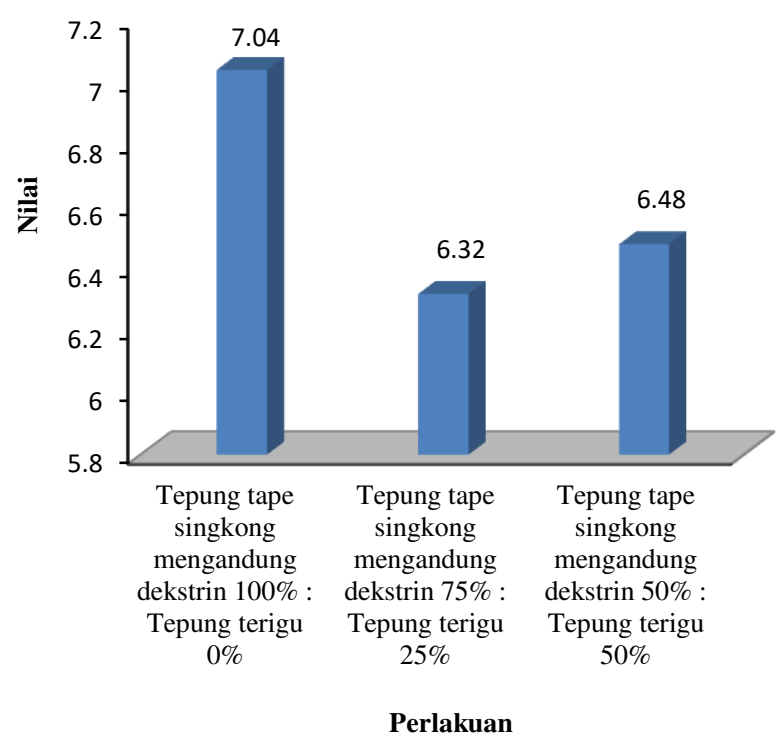

Gambar 3. Grafik hasil uji organoleptik aroma brownies

Berdasarkan Gambar 3. dapat dilihat jika nilai rata-rata tertinggi terdapat pada perbandingan tepung tape singkong tinggi dekstrin 100\%:0\% tepung terigu dengannilai rata-rata 7,04. Tingkat kesukaan panelis terhadap aroma brownies pada perlakuan $100 \%$ tepung tape singkong mengandung dekstrin berbeda nyata dengan perlakuan lainnya. Perbandingan signifikasi antara perlakuan brownies disajikan pada Tabel 2. 
Tabel 2. Perbandingan signifikasi antara perlakuan brownies

\begin{tabular}{lccc}
\hline Perlakuan & $\begin{array}{l}231 \\
(\mathrm{~A})\end{array}$ & $\begin{array}{l}321 \\
(\mathrm{C})\end{array}$ & $\begin{array}{l}432 \\
(\mathrm{~B})\end{array}$ \\
\hline Rerata & 7,04 & 6,32 & 6,48 \\
\hline $\mathrm{A}-\mathrm{B}=7,04-6,48=0,56>0,54$ & \multicolumn{2}{c}{ Jadi, $\mathrm{A} \neq \mathrm{B}$} \\
$\mathrm{A}-\mathrm{C}=7,04-6,32=0,72>0,57$ & $\mathrm{~A} \neq \mathrm{C}$ \\
$\mathrm{B}-\mathrm{C}=6,48-6,32=0,16<0,59$ & $\mathrm{~B}=\mathrm{C}$
\end{tabular}

Keterangan :

$\mathrm{A}=$ tepung tape singkong mengandung dekstrin $100 \%$ : Tepung terigu $0 \%$

$\mathrm{B}=$ tepung tape singkong mengandung dekstrin $75 \%$ : Tepung terigu $25 \%$

$\mathrm{C}=$ tepung tape singkong mengandung dekstrin $50 \%$ : Tepung terigu $50 \%$

Aroma brownies dengan perbandingan 100\%:0\% lebih disukai karena pada tepung tape singkong mengandung dekstrin terdapat aroma asam dan etanol. Menurut Rambing (2013), adanya aroma asam karena pengaruh dari perlakuan konsentrasi ragi dan waktu fermentasi, sedangkan adanya aroma etanol karena gula sederhana telah terhidrolisis menghasilkan alkohol. Dengan adanya aroma khas dari tape sehingga panelis lebih menyukai aroma brownies dengan perlakuan $100 \%$ tepung tape singkong mengandung dekstrin.

\section{Tekstur}

Tekstur adalah salah satu sifat bahan atau produk yang dapat dirasakan melalui sentuhan kulit atau pencicipan. Ada dua jenis dasar tekstur yaitu, tekstur rill dan tekstur visual. Hasil nilai rata-rata uji organoleptik tekstur pada brownies disajikan pada Gambar 4. Perbandingan tepung tape singkong mengandung dekstrin dengan tepung terigu pada pembuatan produk brownies. Tekstur produk pangan merupakan salah satu komponen yang dinilai dalam uji organoleptik brownies dari tepung tape singkong mengandung dekstrin dan tepung terigu. Adapun nilai rata-rata tekstur brownies dengan tiga perlakuan yaitu 6,84 , 6,44 , dan 5,96. Dari nilai rata-rata tersebut dapat diketahui antara ke-tiga perlakuan tidak jauh berbeda.

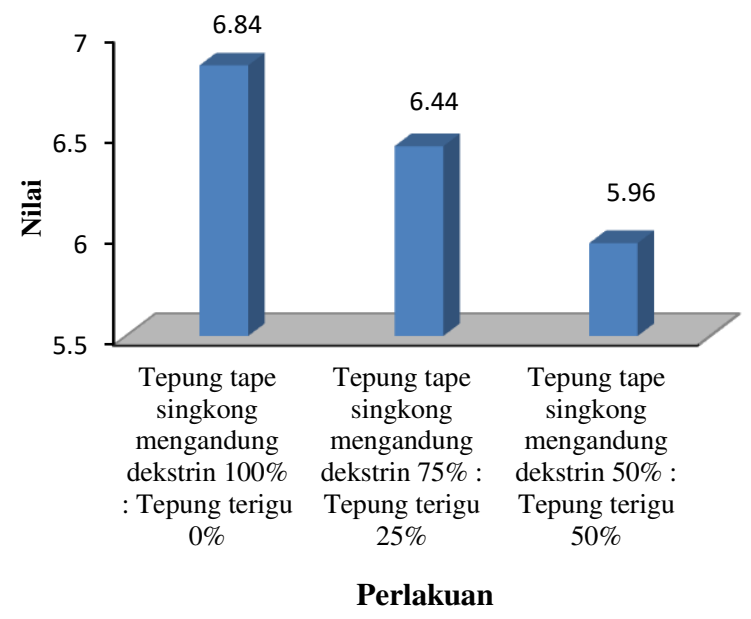

Gambar 4. Grafik hasil uji organoleptik tekstur brownies

Berdasarkan Gambar 4. dapat dilihat jika nilai rata-rata tertinggi terdapat pada perbandingan tepung tape singkong mengandung dekstrin 100\%:0\% tepung terigu dengannilai rata-rata 6,84. Tingkat kesukaan panelis terhadap tekstur brownies pada ketiga perlakuan tidak berbeda nyata. Hal tersebut dapat dilihat pada Tabel 4.

Menurut Aditya (2011) lamanya waktu fermentasi pada ubi jalar dapat mempengaruhi tekstur dari cake ubi jalar tersebut. Semakin lama waktu fermentasi yang digunakan maka tekstur cake ubi jalar semakin lembut.

Tabel 3. Perbandingan signifikasi antara perlakuan brownies

\begin{tabular}{lccc}
\hline Perlakuan & $\begin{array}{l}231 \\
(\mathrm{~A})\end{array}$ & $\begin{array}{l}321 \\
(\mathrm{C})\end{array}$ & $\begin{array}{l}432 \\
(\mathrm{~B})\end{array}$ \\
\hline Rerata & 6,84 & 6,44 & 5,96 \\
\hline $\mathrm{A}-\mathrm{B}=6,84-6,44=0,40<0,66$ & Jadi, $\mathrm{A}=\mathrm{B}$ \\
$\mathrm{A}-\mathrm{C}=6,84-5,96=0,88<0,96$ & $\mathrm{~A}=\mathrm{C}$ \\
$\mathrm{B}-\mathrm{C}=6,44-5,96=0,48<0,71$ & $\mathrm{~B}=\mathrm{C}$ \\
\hline
\end{tabular}

Keterangan :

$\mathrm{A}=$ tepung tape singkong mengandung dekstrin $100 \%$ : Tepung terigu $0 \%$

$\mathrm{B}=$ tepung tape singkong mengandung dekstrin $75 \%$ : Tepung terigu $25 \%$

$\mathrm{C}=$ tepung tape singkong mengandung dekstrin $50 \%$ : Tepung terigu 50\%

Hal tersebut sesuai dengan produk brownies dengan penggunaan tepung tape 
singkong mengandung dekstrin. Pada proses pembuatan tape singkong waktu fermentasi mempengaruhi tekstur tepung yang dihasilkan. Sehingga mempengaruhi produk brownies yang dihasilkan.

\section{Rasa}

Cita rasa adalah suatu cara pemilihan makanan yang harus dibedakan dari rasa makanan tersebut. Cita rasa merupakan atribut makanan yang meliputi penampakan, bau, rasa, tekstur dan suhu. Cita rasa merupakan bentuk kerjasama dari kelima panca indra manusia, yaitu perasa, penciuman, perabaan, penglihatan, dan pendengaran. Hasil nilai rata-rata uji organoleptik rasa pada brownies disajikan pada Gambar 5. Perbandingan tepung tape singkong mengandung dekstrin dengan tepung terigu pada pembuatan produk brownies. Rasa dinilai dengan adanya tanggapan rangsangan oleh indra pengecap (lidah). Rasa merupakan salah satu faktor penting yang menentukan kualitas suatu produk, selain itu rasa dapat mempengaruhi penilaian konsumen terhadap suatu produk. Apabila rasa pada produk terlalu manis, asin, ataupun asam maka konsumen tidak tertarik untuk mengkonsumsinya.

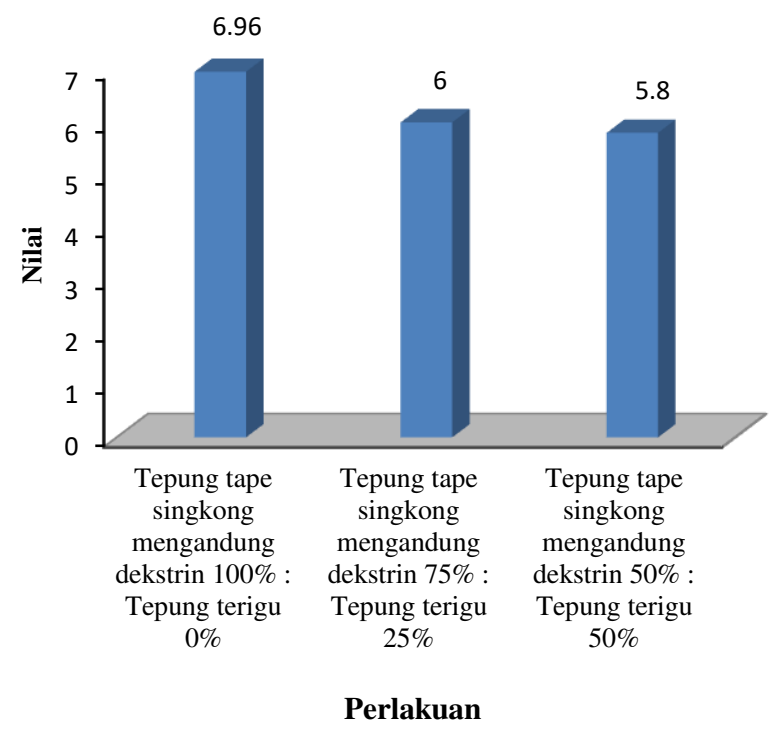

Gambar 5. Grafik Hasil Uji Organoleptik Rasa Brownies

Berdasarkan Gambar 5. dapat dilihat jika nilai rata-rata tertinggi terdapat pada perbandingan tepung tape singkong mengandung dekstrin 100\%:0\% tepung terigu dengan nilai rata-rata 6,96 . Tingkat kesukaan panelis terhadap rasa brownies pada100\% tepung tape singkong mengandung dekstrin berbeda nyata dengan perlakuan lainnya. Hal tersebut dapat dilihat pada Tabel 4.

Tabel 4. Perbandingan signifikasi antara perlakuan brownies

\begin{tabular}{lccc}
\hline Perlakuan & $\begin{array}{l}231 \\
(\mathrm{~A})\end{array}$ & $\begin{array}{l}321 \\
(\mathrm{C})\end{array}$ & $\begin{array}{l}432 \\
(\mathrm{~B})\end{array}$ \\
\hline Rerata & 6,96 & 6,00 & 5,80 \\
\hline $\mathrm{A}-\mathrm{B}=6,96-6,48=0,96>0,68$ & Jadi, $\mathrm{A} \neq \mathrm{B}$ \\
$\mathrm{A}-\mathrm{C}=6,96-6,32=1,16>0,72$ & $\mathrm{~A} \neq \mathrm{C}$ \\
$\mathrm{B}-\mathrm{C}=6,00-6,32=0,20<0,74$ & $\mathrm{~B}=\mathrm{C}$ \\
\hline
\end{tabular}

Keterangan :

$\mathrm{A}=$ tepung tape singkong mengandung dekstrin $100 \%$ : Tepung terigu $0 \%$

$\mathrm{B}=$ tepung tape singkong mengandung dekstrin $75 \%$ : Tepung terigu $25 \%$

$\mathrm{C}=$ tepung tape singkong mengandung dekstrin $50 \%$ : Tepung terigu $50 \%$

Penggunaan tepung tape singkong mengandung dekstrin dalam pembuatan brownies menghasilkan rasa khas tape. Menurut Rambing, (2013) rasa khas tape diperoleh dari konsentrasi ragi serta waktu fermentasi dalam pembuatan tepung tape singkong mengandung dekstrin. Adanya rasa khas tape pada brownies menjadi salah satu alasan panelis lebih menyukai brownies dengan penggunaan $100 \%$ tepung tape singkong mengandung dekstrin.

\section{KESIMPULAN DAN SARAN}

\section{Kesimpulan}

1. Kisaran periode fermentasi terbaik pada pembuatan tepung tape singkong mengandung dekstrin selama 25 jam.

2. Konsentrasi ragi tape terbaik pada pembuatan tepung tape singkong mengandung dekstrin $2 \%$.

3. Pada konsentrasi ragi tape $2 \%$ dengan kisaran periode fermentasi 25 jam 
menghasilkan sifat fisiko-kimia tepung tape singkong mengandung dekstrin, diantaranya nilai kadar dekstrin 9,897\%; gula reduksi $13,453 \%$; kadar air $8,8 \%$; kadar abu $1,6 \%$; total asam $1,96 \%$; nilai $\mathrm{pH} 5,2$; dan rendemen $37,3 \%$.

4. Tingkat kesukaan brownies dengan perbandingan tepung tape singkong mengandung dekstrin 100\%:0\% tepung terigu lebih disukai oleh panelis dengan nilai rata-rata aroma 7,04, tekstur 6,84

\section{Saran}

Perlu adanya penelitian lebih lanjut terkait dengan penganekaragaman pangan, pengembangan dan studi kelayakan usaha pada Agroindustri berbasis tepung tape singkong tinggi dekstrin.

\section{UCAPAN TERIMAKASIH}

Kami ucapkan terima kasih yang sebesar-besarnya, kepada semua pihak, khususnya kepada lembaga penyandang dana, Ditjen Dikti, yang telah mempercayakan kepada kami, dengan dana daftar isian pelaksana anggaran (DIPA 2017).

\section{DAFTAR PUSTAKA}

Asngad A. dan Suprapti. (2009). Lama Fermentasi dan Dosis Ragi Yang Berbeda Pada Fermentasi Gaplek Ketela Pohon (Manihot utillisima, Pohl) varietas Mukibat Terhadap Kadar Glukosa dan Bioetanol. Jurnal Penelitian Sains dan Teknologi 10( 1): 1-9

Badan Pusat Statistik Ketapang. (2013). Ketapang Dalam Angka.

Desrosier NW. 1987. Teknologi Pengawetan Pangan. UI Press. Jakarta

Fennema O R. (1996). Food Chemistry, In ROwen (eds.) Carbohydrates (pp 167196). Marcel Dekker. New York
Hidayat. (2008). Fermentasi dan Mikroorganisme Yang Terlibat. (Online).http://ptp2007.wordpress.co $\underline{\mathrm{m} / 2008 / 06 / 19 / \text { fermentasidan }}$ mikroorganisme -yang terlibat diakses 14 April 2012.

Hidayat, Saukardi dan M. Hidun. (2012). Optimalisasi Penurunan Kandungan Oligosakarida Pada Pembuatan Tepung Ubi Jalar. Jurnal Teknologi Pertanian.

Hidayat, M C Padaga dan S Suhartini. (2006). Mikrobiologi Industri. Penerbit Andi, Yogyakarta.

Jacobs. (1962). Chemical Analysis of Food and Food Products. Third Edition. D. Van Nostrand Comp. Inc.

Kusnandar, F., (2010). Kimia Pangan Komponen Makro. Penerbit Dian Rakyat, Jakarta

Medikasari, Marniza dan E Desiana. (2009). Produksi Tepung Uni Kayu Berprotein : Suatu Kajian Awal Karakteristik Berdasarkan Lama Fermentasi dan Jumlah Inokulum Dengan Menggunakan Ragi. Seminar Hasil Penelitian \& Pengabdian Kepada Masyarakat,. Unila Lampung. Hal 5260

Rambing V. (2013). Rekayasa Pembuatan Tepung Singkong Tinggi Dekstrin, dan Aplikasinya Pada Produk Minuman Instan. Jurnal Teknologi Pertanian

Retno, R. (2009). Peuyeum.(Online) http://wikipedia.org/wiki/peuyeum.co .id. diakses 17 Mei 2012.

Santosa A. (2011). Serat Pangan (Dietary Fiber) dan Manfaatnya Bagi Kesehatan. Jurnal Magistra. 75( 3 ): $35-40$

Soetanto E. (2008). Tepung Kasava dan Olahannya. Penerbit Kanisius. Yogyakarta

Subagio A. (2007). Industrialisasi Modified Cassava Flour (MOCAF) sebagai 
Bahan Baku Industri Pangan untuk Menunjang Diversifikasi Pangan Pokok Nasional. Fakultas Teknologi Pertanian. Universitas Jember. Jember

Sudarmadji S. (1996). Dasar-Dasar Mikrobiologi Pangan. PAU Pangan dan Gizi UGM. Yogyakarta

Sudarmadji S, B Haryono dan Suhardi. (1997). Prosedur Analisa Bahan Makanan dan Pertanian. Liberty Yogyakarta dan PAU Pangan dan Gizi UGM. Yogyakarta

Suprapti L M. (2005). Tepung Tapioka Pembuatan dan Pemanfaatannya. Kanisius. Yogjakarta

Zuhriani F. (2015). Kualitas Organoleptik Brownies Kukus Dari Tepung Beras Hitam. Skripsi. Program Studi Pendidikan Biologi, Fakultas Keguruan dan Ilmu Pendidikan, Universitas Muhammadiyah Surakarta. Jawa Tengah 